\title{
THE INFLAMMATORY PROCESS CORRECTION IN RATS WITH BENIGN PROSTATIC HYPERPLASIA*
}

\author{
N. M. Brechka', V. V. Kozar², V. O. Bondarenko', \\ D. V. Morozenko ${ }^{2}$, Ye. M. Korenyeva ${ }^{1}$, F. S. Leontieva ${ }^{3}$ \\ ${ }^{1}$ SI «V. Danilevsky Institute for Endocrine Pathology Problems \\ of NAMS of Ukraine", Kharkiv, Ukraine; \\ ${ }^{2}$ National University of Pharmacy, Kharkiv, Ukraine; \\ ${ }^{3}$ Sytenko Institute of Spine and Joint Pathology NAMS of Ukraine, Kharkiv, Ukraine \\ natalia01073@gmail.com
}

Benign prostatic hyperplasia (BPH) is the common spread disease that affects 50-80\% of the aged male population. Benign prostatic hyperplasia $(\mathrm{BPH})$ is being a considerable problem of the men's public health because of the often occurrence of the associated symptoms of the lower urinary tract (LUTS) and, as a rule, of the erectile dysfunction [1]. BPH is a progressive disease that mainly is characterized by LUTS deterioration over time, and in some patients by serious consequences development as the acute urinary retention and the necessity to conduct the surgery that relates to the $\mathrm{BPH}$. BPH complications often cause the impaired quality of life [2].

The number of patients suffering from $\mathrm{BPH}$ is constantly increased in Ukraine and world wide. According to the data of the State Institution «V. Danilevsky Institute for Endocrine
Pathology Problems of National Academy of Medical Science of Ukraine» the BPH prevalence in Ukraine in 2013 made 1132.9 for 100.000 adult male population [3]. In 2016 the $\mathrm{BPH}$ prevalence in Ukraine made 1081.6 among men over 18.273.3 among men of working age and 4050.0 among men older than the working age [4]. The similar results are shown by the French authors, who confirm the constant and considerable increase in the number of patients with $\mathrm{BPH}$ who are being treated. Patients with BPH consist of around $30 \%$ of all patients who seek urological assistance in the clinic $[5,6]$.

Despite the great number of studies, the $\mathrm{BPH}$ etiology is considered to be multifactorial, and the pathogenesis insufficiently clarified, which delays timely identification of patients with increased risk of $\mathrm{BPH}$ development

* The research was carried out as part of investigation work at the SI «V. Danilevsky Institute for Endocrine Pathology Problems of National Academy of Medical Science of Ukraine» «Optimization of the diagnosis and treatment of reproductive health disorders endocrine genesis in young people» (State registration number: 0111U000177).

Institution, which financed the research: National Academy of Medical Science of Ukraine.

The authors assume responsibility for the published work.

The authors guarantee absence of competing interests and their own financial interest when carrying out the research and writing the article.

The manuscript was received by the editorial staff 23.12.2019. 
and progression and its early treatment [7]. Androgens and age are traditionally main determinants of prostate enlargement, but the role of chronic inflammation in BPH pathogenesis is being potentially important in recent years. The observation of histological changes in hypertrophied prostatic glands samples of patients with $\mathrm{BPH}$ have shown that inflammation plays a certain role in BPH and LUTS development. Thus, it has been shown in the work [8] that in 162 cases of surgically removed hyperplastic prostate, the inflammatory frequency made $98.1 \%$. Herewith, the isolated glandular inflammation was the most common morphologic pattern, which was characterized by intravascular neutrophils, and foamy macrophages, and chronic inflammatory cells in the surrounding stroma. Further studies have confirmed the relevance of inflammation in $\mathrm{BPH}$ pathogenesis. It has been shown that the hypertrophied prostate has chronic inflammatory infiltrates, presented by chronically activated T-cells and macrophages that produce proinflammatory cytokines (IL-2, IFNY, IL-6, etc.) and can maintain fibro-muscular growth of $\mathrm{BPH}$. One of the explanations of it can be the fact that the inflammatory reaction is maintained on the one hand because of the release of prostate autoantigens after tissue damage and on the other hand of weakening the function of suppressor cells population that actively inhibited the recognition of prostatic antigens [9]. It also has been shown that the human prostatic stromal cells, obtained from BPH tissue, can actively facilitate the inflammatory process by themselves, secreting proinflammatory cytokines and chemokines that induce fibromuscular growth of prostate tissue by autocrine or paracrine regulation [10].

Today, it is considered that the chronic prostate inflammation is one of the $\mathrm{BPH}$ mechanisms that causes disease progression i. e. prostate enlargement and symptoms of urinary disorders [11]. Considering the important role of chronic inflammation in BPH pathogenesis, the conception of pharmacological treatment of $\mathrm{BPH}$ has changed, and now it is aimed at research and application of drugs with an important property of anti-inflammatory effects [12].

The aim of the work was to evaluate the impact of Chondroitin sulphate, Bioglobin-U and Tribestan on the indicators of inflammation under conditions of experimental benign prostatic hyperplasia and compared to the effects of other prostate protectors.

\section{MATERIALS AND METHODS}

Drug activity studies were performed on white non-linear male rats weighing 300-350 g. Animals were kept under standard vivarium conditions. Animal care and handling (including euthanasia) during the experiment were carried out in compliance with the rules of the European Convention on the Protection of Vertebrate Animals Used for Experimental and Scientific Purposes (Strasbourg, 1986) and the provisions of the General Ethical Principles for Animal Experiments (Kyiv, 2001).

Model of benign BPH was provoked by intraperitoneal administration of sulpiride (Eglonil, series 0Y018, 0Y019, No UA/3818/03/01, Sanofi Aventis, Ukraine) at a dose of $40 \mathrm{mg} / \mathrm{kg}$ of animal body weight during 30 days.

This model is characterized by the development of hyperplasia of the lateral parts of the prostate that correlates with similar pathological changes of the prostatic gland in humans [13].
After BPH modeling the rats were administered with drugs: Chondroitin sulphate, Chondroitin sulphate in combination with Tribestan, Tribestan (manufactured by Sopharma, Bulgaria) and Bioglobin-U (a proteinised watersalt extract from a human placenta including polypeptides $3.5-7 \%$, amino acids $50-60 \%$, amino sugars $4-5 \%$, hexuronic acids $8-9 \%$, produced by CJSC Biolik, Kharkiv). The comparison drug was Prostaplant forte produced by Schwabe company, Germany.

Animals were divided into the following groups: group 1 - intact control; group $2-$ control pathology (sulpiride-induced $\mathrm{BPH}$ ); group $3-$ control pathology + administration of Prostaplant forte at a dose of $35 \mathrm{mg} / \mathrm{kg}$; group 4 - control pathology + administration of Chondroitin sulfate substance at a dose of $60 \mathrm{mg} / \mathrm{kg}$; group 5 - control pathology + administration of Tribestan at a dose of $60 \mathrm{mg} / \mathrm{kg}$; group 6 - control pathology + administration 
of Chondroitin sulfate in combination with Tribestan in the above doses; group 7 - control pathology + administration of Bioglobin- $U$ at a dose of $200 \mu \mathrm{l} / \mathrm{kg}$.

The drugs were administrated in the treatment mode from the $30^{\text {th }}$ to the $51^{\text {st }}$ day of the experiment after the $\mathrm{BPH}$ modeling is complete. In each group, the number of animals was 8 male rats. After the end of the study, the rats were removed from the experiment by rapid decapitation under light ether anesthesia on the $52^{\text {nd }}$ day of the experiment.

C-reactive protein (CRP) level, the ESR and leukocyte count were studied. CRP concentration in rat blood serum was determined by the semi-quantitative method of latex agglutination according to $[14,15]$. The sensitivity of the diagnosticum was $0.5 \mathrm{mg} / \mathrm{l} \mathrm{CRP}$.
The leukocyte count was determined by counting cells in the Goryaev chamber; the erythrocyte sedimentation rate (ESR) was determined by the Panchenkov method.

Statistical processing of the obtained results was performed using parametric and non-parametric methods. As a result of the normal distribution, the arithmetic mean and its statistical error were calculated $\left(\overline{\mathrm{X}}_{ \pm} \mathrm{S}_{\overline{\mathrm{X}}}\right)$; if the data were not consistent with the normal distribution, the median $(\mathrm{Me})$, minimum and maximum data $(\min \div \max )$ were calculated. Newman-Keuls method, nonparametric Wilcoxon-Mann-Whitney U-test and KruskalWallis H-test were used to analyze differences. Critical level of significance was assumed to be equal to or less than $0.05(p \leq 0.05)$.

\section{RESULTS AND THEIR DISCUSSION}

It has been studied out that there was an increase in the number of leukocytes and ESR 1.4 times compared to intact animals $(\mathrm{p} \leq 0.05)$ in animals of the Control pathology group at the end of the experiment and that indicates the presence of inflammation in the $\mathrm{BPH}$ simulation (Table 1). As it is known that in the acute process such general clinical indicators of inflammation as the number of leukocytes and ESR grow at times and even tens of times, the results obtained indicate slight process intensity more characteristic of the chronic course.
Our assessment results of peripheral blood in animals with sulpiride model of prostate hyperplasia confirm the presence of inflammation that coincides with the results of other studies that have also demonstrated that increased concentrations of cytokines, cells, and other inflammatory factors were found in the blood and the tissue of the prostate of patients with BPH.

The administration of test drugs in rats with $\mathrm{BPH}$ helped to reduce the manifestation of inflammation that confirms the anti-inflammatory properties of drugs. Our findings are

Peripheral blood indicators

under the impact of drugs on the BPH model

and subject to pharmacological correction, $\left(\overline{\mathrm{X}}_{ \pm} \mathrm{S}_{\overline{\mathrm{X}}}\right),(\mathrm{n}=8)$

\begin{tabular}{|c|c|c|}
\hline \multirow{2}{*}{ Animal group } & \multicolumn{2}{|c|}{ Indicators } \\
\hline & Leukocytes, $10^{9} / 1$ & ESR, $\mathrm{mm} / \mathrm{hr}$ \\
\hline Intact control & $9.97 \pm 0.35$ & $8.10 \pm 0.27$ \\
\hline Control pathology $(\mathrm{BPH})$ & $14.00 \pm 0.43^{1)}$ & $11.25 \pm 0.36$ \\
\hline BPH + Prostaplant forte & $11.40 \pm 0.45^{2)}$ & $10.20 \pm 0.38^{2)}$ \\
\hline $\mathrm{BPH}+$ Chondroitin sulfate & $10.52 \pm 0.45^{2)}$ & $9.4 \pm 0.37^{2)}$ \\
\hline $\mathrm{BPH}+$ Tribestan & $12.20 \pm 0.50^{2)}$ & $10.60 \pm 0.45^{2)}$ \\
\hline $\mathrm{BPH}+$ Chondroitin sulfate + Tribestan & $12.31 \pm 0.31^{2)}$ & $10.40 \pm 0.46^{2)}$ \\
\hline $\mathrm{BPH}+$ Bioglobin-U & $10.60 \pm 0.47^{2)}$ & $9.35 \pm 0.32^{2)}$ \\
\hline
\end{tabular}

Remarque:

1) Statistically significant differences compared to intact control group data, $\mathrm{p} \leq 0.05$.

2) Statistically significant differences compared to control pathology group data, $\mathrm{p} \leq 0.05$. 
supported by other studies which also showed a positive result for the course of $\mathrm{BPH}$ with the use of drugs with anti-inflammatory properties [16]. It should be noted that Chondroitin sulfate and Bioglobin- $U$ was not inferior to the action of the comparison drug Prostaplant forte for the normalization of the number of leukocytes and exceeded the impact of the reference drug for reducing ESR. At the same time Tribestan both independently and in combination with Chondroitin sulfate (where the doses of both drugs were halved) had a weaker antiinflammatory effect.

According to the literature, chronic inflammation associated with BPH has a direct relationship with prostate enlargement and promotes clinical progression of the syndromes related to $\mathrm{BPH}$. Therefore, it is important to search for adequate markers of inflammation that can be used to separate high-risk $\mathrm{BPH}$ patients or the symptoms associated with this condition. One of the highlighted markers is CRP. Despite the fact that CRP refers to nonspecific indicators of inflammation its informativeness was demonstrated in patients with $\mathrm{BPH}$. In particular, it is shown that in men with concentration of CRP higher $>3.0 \mathrm{mg} / \mathrm{l}$ 1.47 times more likely to have three or more symptoms of BPH/LUTS than in men with concentration of CRP lower $3.0 \mathrm{mg} / \mathrm{l}$ [17]. Today, studies on the association between CRP levels in serum and BPH/LUTS are continuing as well as to predict the results of drug treatment for men with BPH/LUTS [18].
According to the results of the proposed concentration of CRP in rats with control pathology we recorded a 2 -fold increase in this indicator compared to the intact group of animals $(\mathrm{p} \leq 0.05)$ (Table 2).

Test drugs decreased credibly the concentration of CRP in rats with BPH. When comparing the action of drugs, the effect was more significant with Chondroitin sulfate and Bioglobin-U and not only in comparison with animals of the control pathology but also when comparing the results of the comparison drug Prostaplant forte. Tribestan both independently and in combination with Chondroitin sulfate showed less effectiveness in reducing inflammation compared to Chondroitin sulfate and Bioglobin-U.

In our study Chondroitin sulfate and Bioglobin-U showed more pronounced anti-inflammatory properties on the $\mathrm{BPH}$ model they are stimulants of metabolic processes. Chondroitin sulfate is attributed to glycosaminoglycans, i. e. connective tissue components, which mechanism is aimed at inhibiting the action of proteolytic enzymes, oxygen radicals, mediators of inflammation, apoptosis processes and improving the processes of microcirculation and regulation of cell proliferation. As the disruption of connective tissue functions accompanies the development of most human diseases the prostate including [19], the results obtained of the use of exogenous Chondroitin sulfate with BPH may indicate a positive effect of the drug on the metabolism/function of the

\section{Concentration of CRP in rats on the BPH model and subject to pharmacological correction, $(\mathrm{Me}, \min \div \max ),\left(\overline{\mathrm{X}} \pm \mathrm{S}_{\overline{\mathrm{X}}}\right), \mathrm{n}=8$}

\begin{tabular}{c|c|c|c}
\hline Group & $\mathbf{M e}, \mathbf{m g} / \mathbf{l}$ & $\mathbf{m i n} \div \mathbf{m a x}, \mathbf{m g} / \mathbf{l}$ & $\overline{\mathbf{X}} \pm \mathbf{S}_{\overline{\mathbf{x}}}$ \\
\hline Intact control & $2^{2}$ & $2 \div 2$ & $2 \pm 0$ \\
\hline Control pathology (BPH) & $4^{1)}$ & $4 \div 4$ & $4 \pm 0$ \\
\hline BPH + Prostaplant forte & $2^{2)}$ & $2 \div 4$ & $2.75 \pm 1.04$ \\
\hline BPH + Chondroitin sulfate & $2^{2)}$ & $1 \div 2$ & $1.75 \pm 0.46$ \\
\hline BPH + Tribestan & $3^{2)}$ & $2 \div 4$ & $3.00 \pm 0.87$ \\
\hline BPH + Chondroitin sulfate + Tribestan & $2^{2)}$ & $1 \div 4$ & $2.50 \pm 1.10$ \\
\hline BPH + Bioglobin-U & $2^{2)}$ & $1 \div 2$ & $1.88 \pm 049$ \\
\hline
\end{tabular}

\section{Remarque:}

1) Statistically significant differences compared to intact control group data, $\mathrm{p} \leq 0.05$.

2) Statistically significant differences compared to control pathology group data, $\mathrm{p} \leq 0.05$. 
connective tissue. The impact of Bioglobin-U, related to biogenic stimulants that have important regulatory and reparative properties, was correlated with action of Chondroitin sulfate in response to inflammation.

Thus, our study demonstrated the presence of inflammation in experimental benign prostatic hyperplasia confirmed by probable increases in leukocyte count, and ESR, and CRP concentration level. The intensity of inflamma- tion can be attributed to chronic. The use of drugs of different pharmacological groups reduced the manifestation of inflammation, however, Chondroitin sulfate and Bioglobin-U were more effective. Assessment of changes in CRP concentration with $\mathrm{BPH}$ and subject to pharmacological correction suggests that CRP can be used in clinical practice to assess patients with BPH/LUTS, effectiveness of treatment and prognosis for quality of life.

\section{CONCLUSIONS}

1. The sulpiride model of prostate hyperplasia is characterized by an increase in the number of leukocytes and ESR and the concentration of CRP which degree of growth can be attributed to the manifestations of chronic inflammation.

2. The studied drugs Chondroitin sulfate, Bioglobin-U, Tribestan and Tribestan in combination with Chondroitin sulfate have showed clear anti-inflammatory properties as confirmed by a decrease in leukocyte count and ESR and CRP concentration in rats with experimental benign prostatic hyperplasia.

3. The studied drugs Chondroitin sulfate and Bioglobin-U that have clear anti-inflammatory properties can be recommended for use in cases of benign prostatic hyperplasia to reduce inflammation.

\section{REFERENCES}

1. Kardasevic A, Milicevic S. Med Arch 2016; 70(6): 449452. doi: 10.5455/medarh.2016.70.449-452.

2. Zattoni F, Ficarra V, Novara G. Urologia 2017; 84(3): 153-157. doi: 10.5301/uro.5000220.

3. Bojko AI, Shmulichenko OV. Ukr Med Chasopys 2017; 4(120), available at: https://www.umj.com.ua/article/ 113154/prognostichni-faktori-riziku-zberezhennya-disfunktsiyi-sechovogo-mihura-pislya-hirurgichnogo-likuvannya-patsiyentiv-iz-dobroyakisnoyu-giperplaziyeyuperedmihurovoyi-zalozi.

4. Sajdakova NO, Stus' VP, Dmytryshyn SP, et al. Urologija 2018: 5-12. doi: 10.26641/2307-5279.22.4.2018. 152449 .

5. Robert G, De La Taille A, Descazeaud A. Prog Urol 2018; 28(15): 803-812. doi: 10.1016/j.purol.2018.08.005.

6. Meshkov IO, Kulchavenya EV, Shevchenko SY, Neimark AI. Urologiia 2018; (4): 72-80.

7. Shimizu S, Shimizu T, Higashi Y, Saito M. Nihon Yakurigaku Zasshi 2019; 154(5): 250-254. doi: 10.1254/ fpj.154.250.

8. Kohnen PW, Drach GW. J Urol 1979; 121(6): 755-760.

9. Nickel JC, Freedland SJ, Castro-Santamaria R, Moreira DM. J Urol 2017; 198(1): 122-128. doi: 10.1016/j. juro.2017.01.035.
10. Hu J, Zhang L, Zou L, et al. Int J Urol 2015; 22(12): 1138-1142. doi: 10.1111/iju.12914.

11. Robert G, Salagierski M, Schalken JA, de La Taille A. Prog Urol 2010; 20(6): 402-407. doi: 10.1016/j.purol. 2010.03.007.

12. Pigat N, Reyes-Gomez E, Boutillon F, et al. Front Pharmacol 2019; 29;10: 311. doi: 10.3389/fphar.2019.00311.

13. Van Coppenolle F, Le Bourhis X, Carpentier F, et al. Prostate 2000; 43(1): 49-58. doi: 10.1002/(SICI)10970045(20000401)43:1<49::AID-PROS7>3.0.CO;2-J.

14. Patent 38911. Sposib vyznachennja koncentracii' S-reaktyvnogo bilka ekspres-metodom.

15. Wegner KA, Mueller BR, Unterberger CJ, et al. J Pathol 2019. doi: 10.1002/path.5363.

16. Urios A, Ordoño F, García-García R, et al. Sci Rep 2019; 9(1): 17119. doi: 10.1038/s41598-019-53136-y.

17. Rohrmann S, De Marzo AM, Smit E, et al. Prostate 2005; 62(1): 27-33.

18. Shun-Fa Hung, Shiu-Dong Chung, Hann-Chorng Kuo. PLoS One 2014; 9(1): e85588. doi: 10.1371/journal.pone. 0085588 .

19. Iczkowski KA. Surg Pathol Clin 2018; 11(4): 687-712. doi: 10.1016/j.path.2018.07.001. 


\title{
КОРЕКЦІЯ ЗАПАЛЬНОГО ПРОЦЕСУ У ЩУРІВ ІЗ ДОБРОЯКІСНОЮ ГІПЕРПЛАЗІЄЮ ПЕРЕДМІХУРОВОЇ ЗАЛОЗИ
}

\author{
Бречка Н. М'., Козар В. В. ${ }^{2}$, Бондаренко В. О. ${ }^{1}$, \\ Морозенко Д. В. ${ }^{2}$, Коренєва Є. М. ${ }^{1}$, Леонтьєва Ф. С. ${ }^{3}$ \\ ${ }^{1}$ ДУ «Інститут проблем ендокринної патологї̈ ім. В. Я. Данилевського НАМН України», \\ м. Харків, Україна; \\ ${ }^{2}$ Національний фбармацевтичний університет, м. Харків, Украйна; \\ ${ }^{3}$ ДУ «Інститут патологї̈ хребта та суглобів ім. профб. М. І. Ситенка НАМН України», \\ м. Харків, Україна \\ natalia01073@gmail.com
}

Доброякісна гіперплазія передміхурової залози (ДГПЖ) - поширене захворювання, яке вражає 50-80 \% чоловічого населення у віці. Виходячи із важливої ролі хронічного запалення в патогенезі ДГПЗ, також змінилася концепція фармакологічного лікування ДГПЗ, яка направлена на дослідження і застосування препаратів, важливою властивістю яких є наявність протизапальних ефектів. Метою було оцінити вплив Хондроїтину сульфату, «Біоглобіну-У» та Трибестану на показники запалення в умовах експериментальної доброякісної гіперплазії передміхурової залози та у порівнянні з едектами інших простатопротекторів. Модель ДГПЗ викликали внутрішньочеревинним веденням сульпіриду (Еглоніл) в дозі 40 мг/кг маси тіла тварини протягом 30 днів. Модель характеризується розвитком гіперплазії латеральних частин простати, що корелюе з аналогічними патологічними змінами передміхурової залози у людини. Після моделювання ДГПЗ щурам вводили препарати Хондроїтин сульфат, Хондроїтин сульфат у поєднанні з Трибестаном, препарат Трибестан та препарат «Біоглобін-У» (протеїнізований водно-сольовий екстракт із плаценти людини). Препарати вводили з 30-го по 51-й день експерименту після завершення моделювання ДГПЗ. Досліджували рівень C-реактивного білку (СРБ), показник швидкості осідання еритроцитів (ШОЕ) та кількість лейкоцитів. Доведено, що сульпіридна модель гіперплазії передміхурової залози характеризується підвищенням кількості лейкоцитів та ШОЕ і концентрації СРБ, ступінь зростання яких можна віднести до проявів хронічного запалення. Досліджувані препарати проявили виразні протизапальні властивості, що підтвержується зменшенням кількості лейкоцитів та ШОЕ і концентрації СРБ у щурів 3 експериментальною доброякісною гіперплазією передміхурової залози. За результатами дослідження Хондроїтину сульфат, «Біоглобіну-У» мали більш виразні протизапальні властивості. Хондроїтину сульфат зменшував ШОЕ ефективніше за препарат порівняння Простаплант форте. Досліджувані препарати Хондроїтину сульфат та «Біоглобіну-У», які мають виразні протизапальні властивості, можна рекомендувати до застосування при доброякісній гіперплазії передміхурової залози для зменшення проявів запалення.

К л ючові с лов а: доброякісна гіперплазія передміхурової залози, С-реактивний білок, андрогени, хондроїтин сульфат.

\section{КОРРЕКЦИЯ ВОСПАЛИТЕЛЬНОГО ПРОЦЕССА У КРЫС С ДОБРОКАЧЕСТВЕННОЙ ГИПЕРПЛАЗИЕЙ ПРЕДСТАТЕЛЬНОЙ ЖЕЛЕЗЫ}

\author{
Бречка Н. М. ${ }^{1}$, Козар В. В. ${ }^{2}$, Бондаренко В. А. ${ }^{1}$, \\ Морозенко Д. В. ${ }^{2}$, Коренева Е. М. ${ }^{1}$, Леонтьева Ф. С. ${ }^{3}$ \\ ${ }^{1}$ ГУ «Институт проблем эндокринной патологии им. В.Я. Данилевского НАМН Украины», \\ г. Харьков, Украина; \\ ${ }^{2}$ Национальный фбармацевтический университет, г. Харьков, Украина: \\ ${ }^{3}$ ГУ «Институт патологии позвоночника и суставов им. профб. М. И. Ситенко НАМН Украинь», \\ г. Харьков, Украина; \\ natalia01073@gmail.com
}

Доброкачественная гиперплазия предстательной железы (ДГПЖ) - распространенное заболевание, которое поражает 50-80 \% мужского населения в пожилом возрасте. Исходя из важной роли хронического воспаления в патогенезе ДГПЖ, также изменилась концепция фрармакологического лечения ДГПЖ, которая направлена на исследование и применение препаратов, важным свойством которых является наличие противовоспалительных эффектов. Целью работы было оценить влияние Хондроитина сульфата, Биоглобина-У и Трибестана на показатели воспаления в условиях экспериментальной доброкачественной гиперплазии предстательной железы и по сравнению с эффектами других простатопротекторов. Модель ДГПЖ вызвали внутрибрюшинным ведением сульпирида (Эглонил) в дозе 40 мг/кг массы тела животного в течение 30 дней. Модель характеризуется развитием гиперплазии латеральных частей простаты, что коррелирует с аналогичными патологическими изменениями простаты у человека. После моделирования ДГПЖ крысам вводили препараты Хондроитина сульфата, Хондроитина сульфата в сочетании с Трибестаном, препарат Трибестан («Sopharma», Болгария) и препарат «Биоглобин-У» (протеинизированный водно-солевой экстракт из плаценты человека). Препараты вводили с 30-го по 51-й день эксперимента после завершения моделирования ДГПЖ. Исследовали уровень С-реактивного белка (СРБ), показатель скорости оседания эритроцитов (СОЭ) и количество 
лейкоцитов. Доказано, что модель гиперплазии предстательной железы характеризуется повышением количества лейкоцитов и СОЭ и концентрации СРБ, степень роста которых можно отнести к проявлениям хронического воспаления. Исследуемые препараты проявили выраженные противовоспалительные свойства, подтвержденные уменьшением количества лейкоцитов и СОЭ и концентрации СРБ у крыс с экспериментальной доброкачественной гиперплазией предстательной железы. По результатам исследования Хондроитина сульфат, Биоглобин-У имели более выраженные противовоспалительные свойства. Хондроитина сульфат уменьшал СОЭ эффективнее препарата сравнения Простаплант форте. Исследуемые препараты Хондроитина сульфат и Биоглобин-У, которые имеют выраженные противовоспалительные свойства, можно рекомендовать к применению при доброкачественной гиперплазии предстательной железы для уменьшения проявлений воспаления.

К л ючевые слова: доброкачественная гиперплазия предстательной железы, С-реактивный белок, андрогены, Хондроитина сульфат.

\section{THE INFLAMMATORY PROCESS CORRECTION IN RATS WITH BENIGN PROSTATIC HYPERPLASIA}

N. M. Brechka ${ }^{1}$, V. V. Kozar ${ }^{2}$, V. O. Bondarenko',

D. V. Morozenko' ${ }^{2}$, Ye. M. Korenyeva ${ }^{1}$, F. S. Leontieva ${ }^{3}$

${ }^{1}$ SI «V. Danilevsky Institute for Endocrine Pathology Problems of NAMS of Ukrainen, Kharkiv, Ukraine;

${ }^{2}$ National University of Pharmacy, Kharkiv, Ukraine;

${ }^{3}$ Sytenko Institute of Spine and Joint Pathology NAMS of Ukraine, Kharkiv, Ukraine natalia01073@gmail.com

Benign prostatic hyperplasia $(\mathrm{BPH})$ is a common disease which affects $50-80 \%$ of the male population in old age. Based on the important role of chronic inflammation in the pathogenesis of BPH the concept of its pharmacological treatment has also changed and an important property of drugs is the presence of antiinflammatory effects. The purpose of the work was to evaluate the effect of Chondroitin sulfate, Bioglobin-U and Tribestan on inflammation in experimental benign prostatic hyperplasia and in comparison with the effects of other prostatoprotectors. BPH was caused by intraperitoneal administration of sulpiride (Eglonil) at a dose of $40 \mathrm{mg} / \mathrm{kg}$ of animal body weight during 30 days. The model represents the development of lateral parts hyperplasia of the prostate, which correlates with similar pathological changes in the human prostate. After rats' BPH were given Chondroitin sulphate at a dose of $60 \mathrm{mg} / \mathrm{kg}$, Chondroitin sulphate in combination with Tribestan at a dose of $60 \mathrm{mg} / \mathrm{kg}$, Tribestan (manufactured by Sopharma, Bulgaria) at a dose of $60 \mathrm{mg} / \mathrm{kg}$, and Bioglobin-U (a proteinised water-salt extract from a human placenta including polypeptides 3.5-7 \%, amino acids 50-60 \%, amino sugars 4-5\%, hexuronic acids 8-9\%, produced by CJSC Biolik, Kharkiv) at a dose of $200 \mu \mathrm{l} / \mathrm{kg}$. The comparison drug was Prostaplant forte produced by Schwabe company, Germany. The drugs were administered from the 30th to the 51st day of the experiment after completion of BPH modeling. The level of C-reactive protein (CRP), sedimentation rate of erythrocytes (SRE), and white blood cell count have been studied. It is proved that the model of prostatic hyperplasia is characterized by an increase in the number of leukocytes and SRE and CRP concentration and the degree of their growth can be attributed to manifestations of chronic inflammation. The studied drugs showed pronounced anti-inflammatory properties and this is confirmed by a decrease of leukocytes number and SRE and the concentration of CRP in rats with experimental benign prostatic hyperplasia. According to the results of a study of Chondroitin sulfate, Bioglobin-U had more pronounced antiinflammatory properties. Chondroitin sulfate reduced SRE more effectively than the comparison drug Prostaplant forte. The studied preparations of Chondroitin sulfate and Bioglobin-U which have pronounced anti-inflammatory properties can be recommended for use in benign prostatic hyperplasia to reduce the manifestations of inflammation.

Key words: benign prostatic hyperplasia, C-reactive protein, sedimentation rate of erythrocytes, connective tissues, androgens, Chondroitin sulfate. 